\title{
The Estrada Real project and endemic diseases: the case of schistosomiasis, geoprocessing and tourism
}

\author{
Omar S Carvalho ${ }^{1 /+}$, Ronaldo GC Scholte ${ }^{1,4}$, Ricardo JPS Guimarães ${ }^{1,4}$, Corina C Freitas ${ }^{7}$, \\ Sandra C Drummond ${ }^{5}$, Ronaldo S Amaral ${ }^{6}$, Luciano V Dutra ${ }^{7}$, Guilherme Oliveira ${ }^{3}$, \\ Cristiano L Massara', Martin J Enk ${ }^{2}$
}

\begin{abstract}
${ }^{1}$ Laboratório de Helmintologia e Malacologia Médica ${ }^{2}$ Laboratório de Esquistossomose ${ }^{3}$ Laboratório de Parasitologia Celular e Molecular Instituto de Pesquisas René Rachou-Fiocruz, Av. Augusto de Lima 1715, Belo Horizonte, MG, Brasil 4Programa de Pós-Graduação, Santa Casa de Misericórdia, Belo Horizonte, MG, Brasil ${ }^{5}$ Secretaria de Estado de Saúde de Minas Gerais, Belo Horizonte, MG, Brasil ${ }^{6}$ Secretaria de Vigilância em Saúde, Ministério da Saúde, Brasília, DF, Brasil 'Instituto Nacional de Pesquisas Espaciais, São José dos Campos, SP, Brasil
\end{abstract}

Geographical Information System (GIS) is a tool that has recently been applied to better understand spatial disease distributions. Using meteorological, social, sanitation, mollusc distribution data and remote sensing variables, this study aimed to further develop the GIS technology by creating a model for the spatial distribution of schistosomiasis and to apply this model to an area with rural tourism in the Brazilian state of Minas Gerais (MG). The Estrada Real, covering about 1,400 km, is the largest and most important Brazilian tourism project, involving 163 cities in $M G$ with different schistosomiasis prevalence rates. The model with three variables showed a $R^{2}=0.34$, with a standard deviation of risk estimated adequate for public health needs. The main variables selected for modelling were summer vegetation, summer minimal temperature and winter minimal temperature. The results confirmed the importance of Remote Sensing data and the valuable contribution of GIS in identifying priority areas for intervention in tourism regions which are endemic to schistosomiasis.

Key words: Geographic Information System - schistosomiasis - Estrada Real project - control - multiple linear regression

Schistosomiasis mansoni is a major parasitic disease in humans and is endemic in 54 countries in South America, the Caribbean, Africa and the Middle East (Chitsulo et al. 2000, Steinmann et al. 2006, Bruun \& Aagaard-Hansen 2008). The trematode Schistosoma mansoni (Sambon 1907), the etiological agent, causes acute, chronic and other clinical forms of disease and/ or complications. The treatment is a single oral dose of the safe drug praziquantel (Katz et al. 1989). The control of schistosomiasis includes chemotherapeutic treatment, adequate sanitation, safe drinking water, sewage draining, treatment and health education. In Brazil, the Biomphalaria glabrata, Biomphalaria tenagophila and Biomphalaria straminea, three species of Biomphalaria water snails, are intermediate hosts for the transmission of $S$. mansoni. B. glabrata is the most important species due to its wide geographic distribution and high susceptibility to infection (Carvalho et al. 2008).

In Brazil, during the last few decades, the distribution of schistosomiasis has been characterised by the spread from rural areas into the periphery of large urban

Financial support: CNPq (302966/2009-9, 380203/2004-9, 308253/2008-6, 490336/2007-8), FAPEMIG (EDP 1775/03, EDT 61775/03, CRA 0070/04), NIH-Fogarty (5D43TW007012), FIC Training Grant (1D43TW006580)

+Corresponding author: omar@cpqrr.fiocruz.br

Received 11 May 2009

Accepted 25 February 2010 centres. Because of the lack of basic sanitation, sewage disposal in natura into hydric collections and the use of contaminated water contribute to the continuing disease and its geographic expansion (Graeff-Teixeira et al. 1999). As recently described, rural tourism and leisure activities in endemic areas by the middle-class urban residents have been driving the exposure and infection in this population subset (Enk et al. 2004, Massara et al. 2008). Although small outbreaks of acute schistosomiasis have occurred among weekend tourists, this mode of transmission has not been well-publicised. These infections may have a negative impact on the tourism business in endemic areas, so new strategies to prevent infection under these circumstances must be developed.

The Estrada Real project - The Estrada Real (Supplementary data), covering about $1,400 \mathrm{~km}$, is one of the largest and most ambitious Brazilian tourism projects; it involves 178 municipalities in the states of Minas Gerais (MG) (163), Rio de Janeiro (8) and São Paulo (7). In $\mathrm{MG}$, the Estrada Real encompasses municipalities with a strong appeal of rural tourism, but these municipalities have prevalence levels of schistosomiasis mansoni that range from $0.06-28.2 \%$. This is a worrisome situation because tourists come to this region from all over Brazil, including areas without schistosomiasis and from other countries that are free of the disease.

Utilization of the Geographical Information System (GIS) in the study of schistosomiasis - Because schistosomiasis is a disease determined in space and time by certain risk factors, the GIS is a very powerful tool for better understanding disease prevalence and the distri- 
bution of multiple risk factors. The use of both GIS and statistical techniques allows for the determination of risk factors and geolocalization of risk areas and may lead to the optimization of resources and choosing the best strategies for disease control (Beck et al. 1997, 2000, Bavia et al. 2001).

The first uses of GIS for schistosomiasis prediction occurred in the Philippines and the Caribbean (Cross et al. 1984). Brown (1994) and Appleton (1978) documented the climate and environmental variables that influenced the distribution of schistosomiasis. GIS was used in a larger scale schistosomiasis study in Asia (Cross et al. 1996, Zhou et al. 2001, Seto et al. 2002, Yang et al. 2005, Zhang et al. 2008) and in several African countries, including Ethiopia (Kristensen et al. 2001, Malone et al. 2001), Egypt (Abdel-Rahman et al. 2001, Malone et al. 1994, 1997), Uganda (Kabatereine et al. 2004), Tanzania (Brooker et al. 2001) and Chad (Beasley et al. 2002, Brooker 2002). In the state of Bahia, Brazil, Bavia et al. (2001) conducted one of the first studies that attempted to correlate disease distribution with environmental variables. Other studies in Brazil using GIS were conducted in Pernambuco (Barbosa et al. 2004) and MG (Freitas et al. 2006, Guimarães et al. 2006, 2008, 2009).

This study aims to further develop the GIS technology by creating a model for the spatial distribution of schistosomiasis and to apply this model to the region of the Estrada Real project in the Brazilian state of MG (Supplementary data). To create this model, we used epidemiologic, meteorological, socio-demographic, sanitation and Remote Sensing data, particularly those produced by recently launched orbital sensors such as the Moderate Resolution Imaging Spectroradiometer (MODIS) and the Shuttle Radar Topography Mission (SRTM).

\section{MATERIALS AND METHODS}

Schistosomiasis prevalence and Biomphalaria data Schistosomiasis prevalence data from 35 municipalities of MG (dependent variable) were gathered from the Secretary of Public Health Surveillance and the Secretary of Health of Minas Gerais. The spatial distribution of these data is presented in Fig. 1.

Biomphalaria data - Data on the distribution of Biomphalaria molluscs, important for the presence or absence of schistosomiasis in Brazil, were provided by the Laboratory of Helminthology and Medical Malacology from Instituto de Pesquisas René Rachou-Fiocruz, MG.

\section{Remote sensing products}

MODIS - The MODIS instrument is operating on both the Terra and Aqua spacecrafts. The data products derived from MODIS observations describe features of the land, oceans and the atmosphere that can be used for studies of processes and trends on local and global scales (Justice et al. 1998). The variables used in this study comprised the Blue, Red, Near Infrared and the Middle Infrared bands, the Enhanced Vegetation Index and the Normalised Difference Vegetation Index (Freitas et al. 2006, Guimarães et al. 2008).
Spectral Linear Mixing Model (SLMM) - The SLMM was the image processing algorithm that generated the fraction images; the proportion of each component (vegetation, soil and shade) inside the pixel was estimated by minimising the sum of square of the errors (Shimabukuro \& Smith 1991).

In this paper, the so-called vegetation, soil and shade fraction images were generated using the MODIS data and the estimated values for the spectral reflectance components were also used as input to the model (Guimarães et al. 2008).

SRTM data - A near-global scale Digital Elevation Model (DEM) was obtained by the SRTM, generating the most complete high-resolution digital topographic database of Earth. SRTM consisted of a specially modified radar system that flew onboard the Space Shuttle Endeavour during an 11-day mission in February of 2000. The ground altitude used in this experiment was given by the value of SRTM DEM for each ground pair of coordinates. The local declivity was derived from SRTM DEM by an appropriate filtering approximation of the first order derivative.

Meteorological variables - The meteorological variables consisted of total precipitation and the minimum and maximum temperatures for summer and winter seasons;



Fig. 1: map showing the prevalence of schistosomiasis in the municipalities of the coverage area of the Estrada Real project in the state of Minas Gerais, Brazil. 
these were obtained from the Brazilian weather forecast centre Centro de Previsão de Tempo e Estudos Climáticos of the Instituto Nacional de Pesquisas Espaciais.

Socio-demographic and sanitation variables - Sanitation (water supply and sewage disposal) and human development index data (for the years of 1991 and 2000) were provided by the National System for Urban Indicators from the Brazilian Minister of the Cities and the Brazilian Institute of Statistic and Geography.

Applied model - In this study, a relationship between schistosomiasis prevalence (dependent variable) and the above-mentioned independent variables from 35 municipalities of the Estrada Real project was established by using multiple regression models.

Mean values for each municipality were used in the models. The relationship among the dependent variable (prevalence, denoted by $P v$ ) and the 42 independent variables, consisting of social, sanitation, meteorological, remote sensing and mollusc distribution data, were analysed in terms of correlation and multicollinearity. Variables having non-significant correlation with $P v$ at the $95 \%$ confidence level were initially eliminated. The remaining variables were used as input variables in the multiple regression model and a selection procedure was performed by the $\mathrm{R}^{2}$ criterion. This selection technique identified a subset of variables by using a coefficient of determination $\mathrm{R}^{2}$ sufficiently close to that when all sig- nificant variables were used in the model. In regression analysis, the $\mathrm{R}^{2}$ is a statistical measure of how well the regression line approximates the real data points.

Because the prevalence data was given at the municipality level, all input variables were integrated inside the municipality boundaries using GIS systems (ArcGis, ENVI) and exported to a standard spreadsheet for statistical analysis and modelling.

The final statistical model was built by using the data of 35 municipalities from where prevalence information was available. By applying the model to the remaining municipalities, a risk map was built for the entire area of the Estrada Real project.

\section{RESULTS}

The final model revealing a $\mathrm{R}^{2}$ of 0.34 included three variables: summer vegetation (VEG_S), summer minimal temperature (Tmin_S) and winter minimal temperature (Tmin_W). Tmin_W was negatively correlated with schistosomiasis prevalence, whereas VEG_S and Tmin_S were positively correlated with prevalence. After determining the $\mathrm{R}^{2}$, the equation $P v$ $=\mathrm{e}^{\left[-9.25+0.04\left(\mathrm{VEG} \_\mathrm{S}\right)+0.81 \text { (Tmin_S) }-0.4(\text { Tmin_W })\right]}-1$ was built to allow estimation of the prevalence for each municipality; $33(20,3 \%)$ municipalities had a prevalence greater than $10 \%$ and $130(7 \%)$ municipalities had a prevalence less than $10 \%$ (Fig. 2A). Fig. 2B shows the plot of the residuals resulting from the difference between observed
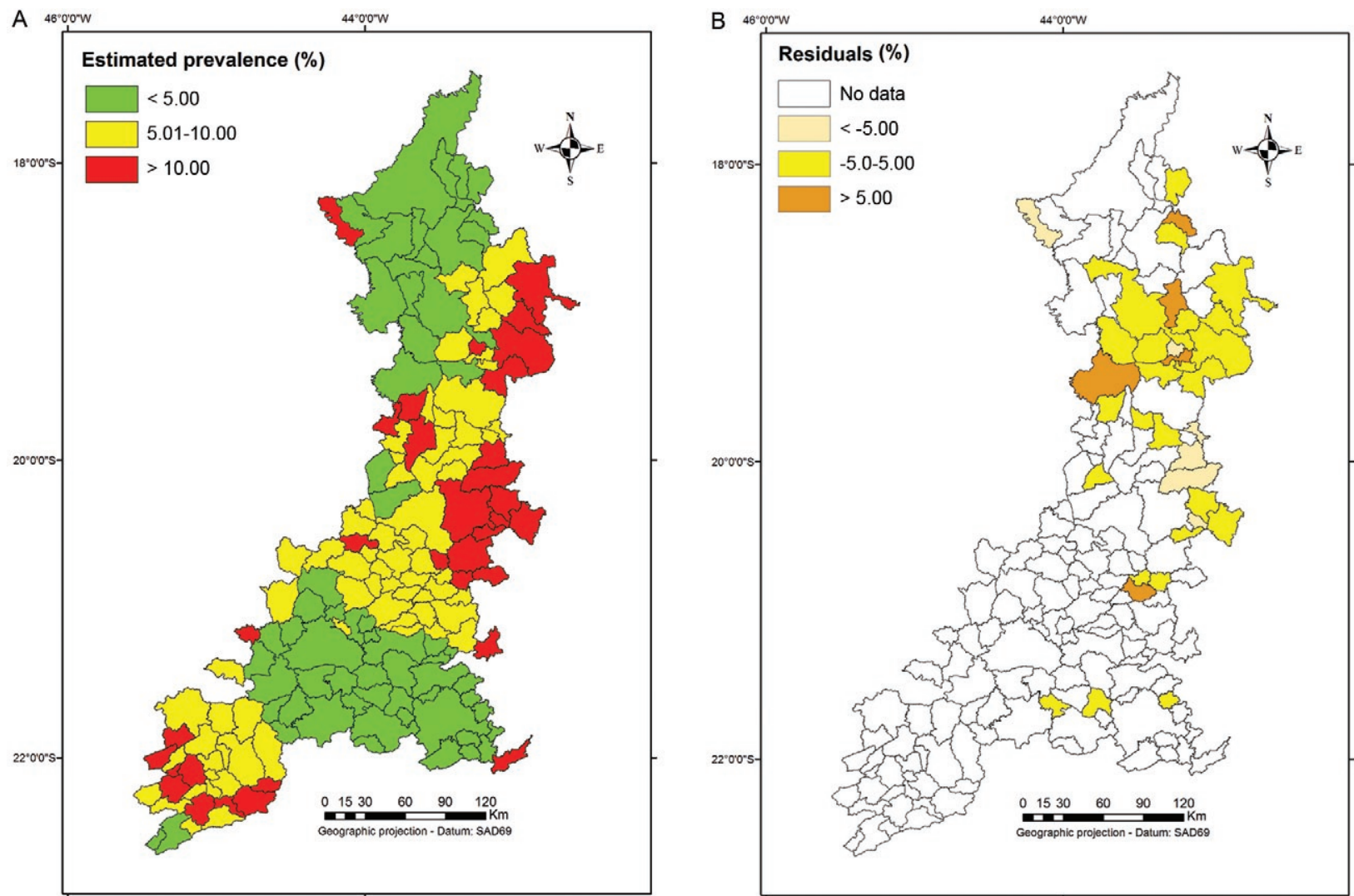

Fig. 2A: map of estimated prevalence of schistosomiasis in the municipalities of the Estrada Real project at the state of Minas Gerais (MG), Brazil; B: map of the residuals in the municipalities of the Estrada Real project at MG. 
(Fig. 1) and estimated schistosomiasis prevalence (Fig. 2A). In Fig. 2B, dark orange represents overestimated values, light orange underestimated values and yellow the municipalities with an accurate estimative. According to Supplementary data, over $80 \%$ of the municipalities of the Estrada Real have untreated sewage and the final destination of the sewage is the river.

\section{DISCUSSION}

Variables from different sources (social, sanitation, meteorological and remote sensing) were used in this study. The equation of estimated $P v$ showed that Tmin_S, Tmin WW (meteorological) and vegetation (remote sensing) were useful variables for the study of schistosomiasis. These same variables were used by Guimarães et al. $(2006,2008)$ to develop a forecast map for schistosomiasis mansoni in MG.

First, the results of this study led to the determination of significant factors related to disease transmission and reconfirmed the importance of Remote Sensing data. These results, compared to other work, suggest a successful role for Remote Sensing data applications in investigating the spatial epidemiology and control of major human helminths (Hassan et al. 1998a, b, Brooker \& Michael 2000, Bavia et al. 2001, Beck et al. 2002, Brooker 2002, Guimarães et al. 2006, 2008). Second and more importantly, our approach facilitated the geographical identification of priority areas for intervention, providing the possibility for more efficient control or surveillance efforts. In this context, the introduced methodology may also serve to direct preventive measures such as environmental education or health awareness programs, especially in regions like the Estrada Real project where tourism is a considerable economic factor.

Therefore, even with a relatively low coefficient of determination and low number of municipalities with information about prevalence, we conclude that the use of GIS, remote sensing and statistical techniques, combined with socio-demographic, epidemiologic and environmental data, together allows for the identification of regional factors associated with the transmission of schistosomiasis and facilitates the delimitation and classification of areas based on their probability for infection with the diseases.

As shown in Supplementary data, in the case of Estrada Real, the environmental and Remote Sensing data were more important to the model construction possibly because more than $80 \%$ of the municipalities have no sewage treatment and waste is destined for the river.

Nevertheless, to improve the model's accuracy for more precise estimates and its application to identify priority areas for intervention on a large scale, it is very important to conduct geo-referenced malacological and prevalence surveys in those municipalities where data are insufficient or not yet available.

\section{REFERENCES}

Abdel-Rahman MS, El-Bahy MM, Malone JB, Thompson RA, El Bahy NM 2001. Geographic information systems as a tool for control program management for schistosomiasis in Egypt. Acta Trop 79: 49-57.
Appleton CC 1978. Review of literature on abiotic factors influencing the distribution and life cycles of bilharziasis intermediate host snails. Malacol Rev 11: 1-25.

Barbosa CS, Araújo KC, Antunes L, Favre T, Piere OS 2004. Spatial distribution of schistosomiasis foci on Itamaracá Island, Pernambuco, Brazil. Mem Inst Oswaldo Cruz 99 (Suppl. I): 79-83.

Bavia ME, Malone JB, Hale L, Dantas A, Marroni L, Reis R 2001. Use of thermal and vegetation index data from earth observing satellites to evaluate the risk of schistosomiasis in Bahia, Brazil. Acta Trop 79: 79-85.

Beasley M, Brooker S, Ndinaromtan M, Madjiouroum EM, Baboguel M, Djenguinabe E, Bundy DA 2002. First nationwide survey of the health of schoolchildren in Chad. Trop Med Int Health 7: 625-630.

Beck L, Bobo M, Kitron U 2002. Remote sensing, GIS and landscape ecology: means for studying disease and global change. In P Martens, T McMichael (eds.), Environmental change, climate and health: issues and research methods, Cambridge University Press, Cambridge, 352 pp.

Beck LR, Lobitz BM, Wood BL 2000. Remote sensing and human health: new sensors and new opportunities. Emerg Infect Dis 6: 217-227.

Beck LR, Rodriguez MH, Dister SW, Rodriguez AD, Washino RK, Roberts DR, Spanner MA 1997. Assessment of a remote sensingbased model for predicting malaria transmission risk in villages of Chiapas, Mexico. Am J Trop Med Hyg 56: 99-106.

Brooker S 2002. Schistosomes, snails and satellites. Acta Trop 82: 207-214.

Brooker S, Hay SI, Issae W, Hall A, Kihamia CM, Lwambo NJ, Wint W, Rogers DJ, Bundy DA 2001. Predicting the distribution of urinary schistosomiasis in Tanzania using satellite sensor data. Trop Med Int Health 6: 998-1007.

Brooker S, Michael E 2000. The potential of geographical information systems and remote sensing in the epidemiology and control of human helminth infections. Adv Parasitol 47: 245-288.

Brown DS 1994. Freshwater snails of Africa and their medical importance, 2nd ed., Taylor and Francis, London, 608 pp.

Bruun B, Aagaard-Hansen J 2008. The social context of schistosomiasis and its control: an introduction and annotated bibliography. World Health Organization, Geneva, 227 pp.

Carvalho OS, Amaral RS, Dutra LV, Scholte RG, Guerra MA 2008. Distribuição espacial de Biomphalaria glabrata, B. straminea $\mathrm{e}$ B. tenagophila hospedeiros intermediários do Schistosoma mansoni no Brasil. In OS Carvalho, PMZ Coelho, HL Lenzi (eds.), Schistosoma mansoni e esquistossomose: uma visão multidisciplinar, Editora Fiocruz, Rio de Janeiro, 1124 pp.

Chitsulo L, Engels D, Montresor A, Savioli L 2000. The global status of schistosomiasis and its control. Acta Trop 77: 41-51.

Cross ER, Newcomb WW, Tucker CJ 1996. Use of weather data and remote sensing to predict the geographic and seasonal distribution of Phlebotomus papatasi in southwest Asia. Am J Trop Med Hyg 54: 530-536.

Cross ER, Sheffield C, Perrine R, Pazzaglia G 1984. Predicting areas endemic for schistosomiasis using weather variables and a Landsat data base. Mil Med 149: 542-544.

Enk MJ, Caldeira RL, Carvalho OS, Schall VT 2004. Rural tourism as risk factor for the transmission of schistosomiasis in Minas Gerais, Brazil. Mem Inst Oswaldo Cruz 99 (Suppl. I): 105-108.

Freitas CC, Guimarães RJ, Dutra LV, Martins FT, Gouvêa EJ, Santos RA, Moura AC, Drummond SC, Amaral RS, Carvalho OS 2006. Remote sensing and geographic information systems for the study of schistosomiasis in the state of Minas Gerais, Brazil, IEEE International Geoscience and Remote Sensing Symposium, Denver, p. 2436-2439. 
Graeff-Teixeira C, dos Anjos CB, de Oliveira VC, Velloso CF, da Fonseca MB, Valar C, Moraes C, Garrido CT, do Amaral RS 1999. Identification of a transmission focus of Schistosoma mansoni in the southernmost Brazilian state, Rio Grande do Sul. Mem Inst Oswaldo Cruz 94: 9-10.

Guimarães RJ, Freitas CC, Dutra LV, Felgueiras CA, Moura AC, Amaral RS, Drummond SC, Scholte RG, Oliveira G, Carvalho OS 2009. Spatial distribution of Biomphalaria mollusks at São Francisco River Basin, Minas Gerais, Brazil, using geostatistical procedures. Acta Trop 109: 181-186.

Guimarães RJ, Freitas CC, Dutra LV, Moura AC, Amaral RS, Drummond SC, Scholte RG, Carvalho OS 2008. Schistosomiasis risk estimation in Minas Gerais state, Brazil, using environmental data and GIS techniques. Acta Trop 108: 234-241.

Guimarães RJ, Freitas CC, Dutra LV, Moura AC, Amaral RS, Drummond SC, Guerra M, Scholte RG, Freitas CR, Carvalho OS 2006. Analysis and estimative of schistosomiasis prevalence for the state of Minas Gerais, Brazil, using multiple regression with social and environmental spatial data. Mem Inst Oswaldo Cruz 101 (Suppl. I): 91-96.

Hassan AN, Beck LR, Dister S 1998a. Prediction of villages at risk for filariasis transmission in the Nile Delta using remote sensing and geographic information system technologies. J Egypt Soc Parasitol 28: 75-87.

Hassan AN, Dister S, Beck L 1998b. Spatial analysis of lymphatic filariasis distribution in the Nile Delta in relation to some environmental variables using geographic information system technology. J Egypt Soc Parasitol 28: 119-131.

Justice CO, Vermote E, Townshend JR, Defries R, Roy DP, Hall DK, Salomonson VV, Privette JL, Riggs G, Strahler A, Lucht W, Myneni RP, Knyazikhin Y, Running SW, Nemani RR, Wan Z, Huete AR, van Leeuwen W, Wolfe RE, Giglio L, Muller JP, Lewis $\mathrm{P}$, Barnsley MJ 1998. The moderate resolution imaging spectroradiometer (MODIS): land remote sensing for global change research. IEEE Trans Geosci Remote Sens 36: 1228-1249.

Kabatereine NB, Brooker S, Tukahebwa EM, Kazibwe F, Onapa AW 2004. Epidemiology and geography of Schistosoma mansoni in Uganda: implications for planning control. Trop Med Int Health 9: $372-380$.

Katz N, Dias EP, de Souza CP, Bruce JI, Coles GC 1989. Rate of action of schistosomicides in mice infected with Schistosoma mansoni. Rev Soc Bras Med Trop 22: 183-186.
Kristensen TK, Malone JB, McCarroll JC 2001. Use of satellite remote sensing and geographic information systems to model the distribution and abundance of snail intermediate hosts in Africa: a preliminary model for Biomphalaria pfeifferi in Ethiopia. Acta Trop 79: 73-78.

Malone JB, Abdel-Rahman MS, El Bahy MM, Huh OK, Shafik M, Bavia M 1997. Geographic information systems and the distribution of Schistosoma mansoni in the Nile delta. Parasitol Today 13: 112-119.

Malone JB, Huh OK, Fehler DP, Wilson PA, Wilensky DE, Holmes RA, Elmagdoub AI 1994. Temperature data from satellite imagery and distribution of schistosomiasis in Egypt. Am J Trop Med Hyg 50: 714-722.

Malone JB, Yilma JM, McCarroll JC, Erko B, Mukaratirwa S, Zhou X 2001. Satellite climatology and the environmental risk of Schistosoma mansoni in Ethiopia and east Africa. Acta Trop 79: 59-72.

Massara CL, Amaral GL, Caldeira RL, Drummond SC, Enk MJ, Carvalho OS 2008. Esquistossomose em área de ecoturismo do Estado de Minas Gerais, Brasil. Cad Saude Publica 24: 1709-1712.

Sambon LW 1907. Descriptions of some new species of animal parasites. Proc Zool Soc London 282-283.

Seto E, Xu B, Liang S, Gong P, Wu W, Davis GM, Qui D, Gu X, Spear R 2002. The use of remote sensing for predictive modeling of schistosomiasis in China. Photogramm Eng Remote Sensing 68: 167-174.

Shimabukuro YE, Smith JA 1991. The least-squares mixing models to generate fraction images derived from remote sensing multispectral data. IEEE Trans Geosci Remote Sens 29: 16-20.

Steinmann P, Keiser J, Bos R, Tanner M, Utzinger J 2006. Schistosomiasis and water resources development: systematic review, meta-analysis and estimates of people at risk. Lancet Infect Dis 6: 411-425.

Yang GJ, Vounatsou P, Zhou XN, Utzinger J, Tanner M 2005. A review of geographic information system and remote sensing with applications to the epidemiology and control of schistosomiasis in China. Acta Trop 96: 117-129.

Zhang Z, Carpenter TE, Chen Y, Clark AB, Lynn HS, Peng W, Zhou Y, Zhao G, Jiang Q 2008. Identifying high-risk regions for schistosomiasis in Guichi, China: a spatial analysis. Acta Trop 107: 217-223.

Zhou XN, Malone JB, Kristensen TK, Bergquist NR 2001. Application of geographic information systems and remote sensing to schistosomiasis control in China. Acta Trop 79: 97-106. 